\title{
A JOURNEY FROM SELF-DISCOVERY TO SELF-CARING: OLDER ADULTS ENGAGING WITH CONTEMPORARY ART ${ }^{1}$
}

\author{
Anne-Marie Émond \\ Département de didactique, Université de Montréal (Canada)
}

\begin{abstract}
Context: Museum education is seen as a means of enriching individuals, creating meaningful situations that generate purpose for visitors. From the point of view of cultural democracy and cultural democratization, museums now realize that they must constantly innovate to meet the diverse and changing needs of communities in which they are embedded, and in so doing, fulfill their social role.

Objectives: This is true when studying art museums, most specifically their contemporary art collection. Contemporary art, no longer primarily based on canonical principles of beauty, is still today considered a challenge for many individuals. In this context, the principal objective of our research program was centered around accessing and understanding the actual experiences of adults. To understand the intellectual functioning of visitors is an avenue in providing useful information for the elaboration of powerful museum programs. This is a key issue, for museum professionals since it is imperative to find ways to provide a diversity of museum experiences for all. More specifically, our paper presents effects of contemporary art exploration on older adults.

Methods: Our research was conducted at the Montreal Museum of Fine Arts. Twenty-four adult visitors aged 65 and over that visited museums more than five times per year were selected. Data was collected using the Thinking Aloud protocol. This approach is one where visitors were asked to articulate ideas, thoughts they might have as they toured the galleries. The verbal comments were recorded, transcribed and analyzed using instruments created in previous research, that is, a typology of dissonances and consonances, the identification of eight mental operations, and these results were put in relation to Pelowski and Akiba's psychological model of a transformative art experience comprising five stages with three possible outcomes to the art experience.

Results: Results indicate the importance of reaching Pelowski and Akiba's meta-cognitive Stage 4 of the aesthetic experience. Engaging with contemporary art seems to be, for the elderly visitor, an exercise in self-discovery where, with contemporary art, it is possible to find meaning. For our visitors, the aesthetic experience has the power of regenerating the self, resulting in self-caring. The museum can then be viewed as a self-care environment that provides elderly visitors with possible transformative aesthetic experiences that can help improve their well-being and quality of life. However, this would require additional research in exploring different museum experiences, considering different artistic periods, and this, as part of a longitudinal study.
\end{abstract}

Keywords: Adult visitors, intellectual functioning, art museums, contemporary art, aesthetic experience.

\section{Rationale of the research}

In the last decade, museums have actively promoted their social value as a community asset. With the aging of the population, it is clear that innovative programs must be put in place to meet the needs of the elderly.

The research project focused on contemporary art appreciation as opposed to historical art, for a number of reasons. As artworks are considered of our time, it was hoped that elderly participants would be able to relate to the representation of today's life or views of the world, presented in the artworks. Instead of focusing on the past, through the exploration of historical art, we wanted to present artworks that were contemporaneous to our elderly visitors. So, on the one hand, contemporary art may have relevance to our participants as some of the subjects being explored, reflect on the society we live in. On the other hand, the way to treat these diverse subject matters might be challenging for them as

${ }^{1}$ This research has been funded by the Social Sciences and Humanities Research council of Canada (SSHRC). 
contemporary art is no longer primarily based on canonical principles of beauty and ask for the viewer to formulate a multitude of interpretations.

To understand the intellectual functioning of visitors during their exploration of contemporary artworks is an avenue in providing useful information for the elaboration of powerful museum programs. This paper addresses how older people understand and engage with contemporary art in a museum context and whether if engaging with contemporary art has an impact on elderly visitors' museum experience.

\section{The choice of participants}

Participants were of mixed gender $(n=24)$, aged 65 to 80 , with different levels of education ranging from less than 12 years of education to post-secondary education.

They were frequent museum goers with more than 5 visits per year. Participants were familiar with the museum context as they were members of the Montreal Museum of Fine Arts. The study received ethical approval from the ethics committee at the Université de Montréal.

\section{Procedure for collecting data}

Data was collected using the Thinking Aloud protocol adapted to visits to museum exhibitions in the 1990s by Dufresne-Tassé and her team. This method consists of recording what the visitor says at the very time of the visit. Visitors, not having to worry about explaining or justifying their comments, have only to say aloud whatever comes to mind (Dufresne-Tassé \& Lefebvre, 1995; Dufresne-Tassé et al., 1998; Ericsson and Simon, 1993). This method has been subjected to numerous tests and adjustments so as to significantly reduce its impact on the functioning of the visitor and may, thus, be employed with confidence. The artwork explorations were between 90 and 150 min' duration and were digitally recorded and transcribed. These constituted the visitor's discourse.

\section{Treatment of data}

The twenty-four transcripts were then coded using existing categories identified in previous research. The coding was first based on a typology of consonances and dissonances so that moments of harmony and conflict could be identified in the participants' discourses. Secondly, eight mental operations were also coded between consonant and dissonant moments (Émond, 2016a, 2016b, 2017). Third, once the discourses coded, results were put in relation to Pelowski and Akiba's (2011) psychological model of art experience. This model presents five different stages of the aesthetic experience: Stage 1: Pre-expectations and self-image; Stage 2: Cognitive mastery and introduction of discrepancy; Stage 3: Secondary control and escape; Stage 4: Meta-cognitive re-assessment; Stage 5: Aesthetic outcome and new mastery, with a total of three possible Outcomes to the aesthetic experience. It is recognized that the conclusion drawn cannot be generalized beyond the data set.

\section{Results and discussion}

\subsection{Meta-cognitive re-assessment and aesthetic outcome and new mastery}

Contemporary art exploration seems to create dissonances as it often challenges the way the visitor appreciates art. As mentioned by Radford (2004), the role of cognitive dissonances is unavoidable in the exploration of contemporary art, as it contains "[the] notion of tension and reconciliation, and of the creative act as speaking to something "within us" and revealing to us something about ourselves..." (p. 56). The visitor that overcomes the challenges inherent to the exploration of contemporary artworks, seems to instigate creativity. In these circumstances, the visitor appears to tolerate ambiguity and is willing to go beyond his comfort zone in his art appreciation (Minissale, 2013).

In Pelowski and Akiba's (2011) psychological model of art experience, as presented by Émond (2018; 2019), all stages have a particular role to play in the quality of visitors' museum experience particularly Stage 4: Meta-cognitive re-assessment as when the visitor completes Stage 4 and enters into Stage 5: Aesthetic outcome and new mastery, he is getting closer to an Outcome 3, that is, a transformative aesthetic experience. As discussed previously, when a visitor overcomes the challenges encountered during a contemporary artwork exploration and withholds a final judgement and pursues the artwork exploration, this allows for other ideas to emerge and in doing so prolongs the aesthetic experience (Gomez, 2007). This favors a situation where the unexpected is pursued. When this occurs during the artwork exploration, there is evidence in the visitor's discourse of metacognitive knowledge, 
experiences and skills (Émond, 2019). The visitor being in a creative pursuit during Stage 4, seems to undergo moments of self-discovery. One participant reported in his discourse such an experience:

But this reminds me of a place and time in my life... Because in ruptures you have like... it's like two colors, ... that's like in illness there, look, when you're told you have cancer you're in the acute phase, ... but it's the same thing in a rupture, it's like... it's that... You don't see anything, you don't know... but you know there are lights somewhere... because, like it or not, when suffering... you know that suffering will stop...

Basically, I realize that the artworks, the artworks come to me emotionally a lot... a lot... and you see what I want, is art that is not too stuffy (MBAM BQ).

The participant sees the contemporary art exploration as an opportunity to reflect on life and realizes the challenging nature of the artwork which instigates an emotional encounter. Pursuing the exploration, the visitor engaged with another artwork and said:

So that's why I find that this... this painting here... this is what I love about it, it's like my life through it. You look at that, it's a dead tree, it's a wound, it's a scar, do you understand? Rocks represent the difficult things... do you understand, that's it. Then there are people, there are people who are doing something, you know. Now look at this, it is like... death... do you understand? I'm confronted at that, at seventy-one years of age, life expectancy is eighty-five, so I'm probably going to go to one hundred and five years of age, to bother a few more people, but, you know, in the meantime, that's it, do you understand?

And then you look at that and then you say, I regenerate myself when I look at that, see. There's like a concordance between where I'm in my life and that... (MBAM BQ).

When going through Stage 4, art becomes a vehicle to construct and understand the self (Brinck, 2007). This entails that the visitor is engaged in the exploration of the contemporary artwork in a prolonged manner to experience all different stages of the aesthetic experience. Self-discovery might occur through time and possibly through repeat encounters with artworks for the visitor to feel reinvigorated. These museum experiences could be qualified as self-care by visitors themselves.

The museum can be considered as a resource for taking care of oneself. Engaging with contemporary art, which is a product of our society, one in which our elderly visitors live in, can help promote or enhance the personal potential of older visitors and contribute to their well-being. This could be enunciated by defining self-care "as a practice of activities that individuals initiate and carry out on their own by maintaining life, health and well-being" (Hoy, Wagner \& Hall, 2007, p. 457). As mentioned by Camic, Hulbert \& Kimmel, (2017) work is still needed in the elaboration of a definitive theory of well-being. In an attempt to better define the concept, Ryff and Singer (2006) presents the notion of psychological well-being "as comprising six key components, personal growth, self-acceptance, autonomy, purpose in life, positive relationships, and environmental mastery (as cited in Todd, Camic, Lockyer, Thomson \& Chatterjee, 2017, p. 47). Riger and Lavrakas (1981) suggested that well-being is improved when an elderly person can experience a sense of belonging to a community, to be relevant members of society.

The museum can be viewed as a self-care environment that provides elderly visitors with possible transformative aesthetic experiences that can help improve their well-being and quality of life. An elderly person living a transformational aesthetic experience through self-discovery will probably leave the museum with a vivid impression that will be prolonged in time. Being engaged with contemporary art, indicates that elderly visitors encounter challenges in which they discover interconnectedness between different ideas being put forth by artists and this in itself is important for personal change to occur. Considering Pelowski and Akiba's (2011) psychological model of art experience, we can say that for elderly people to take a personal risk in looking at a contemporary artwork that does not match their personal conception of what an artwork should be, is in itself another important first step. Then by being able to make connections with the contemporary artwork and their own prior knowledge is also an important component to consider towards a transformative aesthetic experience and an attitudinal shift. This implies changing views about the contemporary artwork being explored and in parallel a better understanding of the self and the world. Ultimately, this entails what was described in Stage 5, a transformative aesthetic experience, where, in the case of our specific research, an elderly person might seek new forms of art in a quest of altering life experiences, perceiving oneself as an active member of society. This concurs with Banz's views of museums as places that "can appeal to the very intimate needs of the self, being perceived as instruments of self-renewal" (2008, p. 44). As for Monk (2013), museums "through their interactive nature, [...] have the power to confront individuals' schemata and transform the way people view the world" (p. 63). Considering the benefits of being engaged with contemporary artworks, museums can be considered instrumental in offering programs for the elderly to improve psychological well-being and act as places where self-care is possible. Participants in this study, during the post-exploration interview, declared having experienced a worthwhile encounter with contemporary art and considered the possibility of renewing this type of experience. 


\section{Conclusion}

A transformative aesthetic experience is a process. This process begins with a disorienting experience that does not fit within a person's current perspective and cannot be easily resolved. This prompts a person, and in the context of this study, an elderly person to work through diverse assumptions and beliefs about artworks. To pursue the exploration, the person needs to explore different avenues to solve the dilemma. This generates, most of the time, a more inclusive and accommodating outlook than what was envisioned at the beginning of the exploration of the artwork. This kind of museum experience is for the elderly an occasion to go beyond the mere learning of facts and encounter personal outcomes that implies their active role in society as being part of actual debates in acknowledging their own point of view amongst others.

Museums ought to develop their role as places of "societing" a term used by Grimes and Minelli (2016) to propose a new kind of participation. This is to view museums not only as institutions adapting their offers to diverse publics' needs, but as social actors embedded in their communities. Exploiting "societing" in the museum context would translate into giving diverse members within communities, like elderly people, access to their collections, while also providing a unique brand or label such as places for self-caring. In doing so, distinctive experiences would be created in a place where members of communities could meet and share their different perceptions of the world in an open dialogue with the institution and where older adults would have a voice. Museum could foster a "place to be" in the spirit of democracy and cultural democratization. The role and value of museums contributing to self-care and well-being needs further exploration as this would require additional research in exploring different artistic periods, and this, as part of a longitudinal study with healthy older adults and also those with more specific needs that already are experiencing different illnesses attributed to aging.

\section{References}

Banz, R. (2008). Self-directed learning: Implications for museums. The Journal of Museum Education, 33(1), 9-22. Retrieved from: http://www.jstor.org/stable/40479604

Brinck, I. (2007). Situated cognition, dynamic systems, and art: on artistic creativity and aesthetic experience. Janus Head, 9(2), 407-431. Retrieved from: http://www.janushead.org/9-2/brinck.pdf

Camic, P.M., Hulbert, S., \& Kimmel, J. (2017). Museum object handling: A health promoting community-based activity for dementia care. Journal of Health Psychology, 24(6), 787-798. Retrieved from: https://journals.sagepub.com/doi/pdf/10.1177/1359105316685899

Dufresne-Tassé, C. Sauvé, M., Weltzl-Fairchild, A., Banna, N., Lepage, Y., \& Dassa, C. (1998). Pour des expositions muséales plus éducatives, accéder à l'expérience du visiteur adulte. Développement d'une approche. Canadian Journal of Education/Revue canadienne de l'éducation, 23(3), 302-315.

Dufresne-Tassé, C., \& Lefebvre, A. (1995). Psychologie du visiteur de musée: Contribution à l'éducation des adultes en milieu muséal. Montréal, QC: Éditions Hurtubise HMH.

Émond, A.M. (2016a). La pertinence pour les musées de développer des outils de médiations écrites pour l'appréciation de l'art contemporain. In A. Savoie, A.M. Émond, F. Gagnon-Bourget \& P. Gosselin (Eds.), Actes du Colloque sur la recherche en enseignement des arts visuels (pp. 26-32). Montréal, QC: CRÉA.

Émond, A.M. (2016b). Connaître les opérations mentales utilisées par les étudiants à la formation des maîtres pour traiter les œuvres d'art contemporain. In M. Théberge \& F. Chaîné (Eds.), Réfléchir à la formation artistique (48-76). Québec, QC: Éditions FRÉA.

Émond, A.M. (2017). La voix des visiteurs en contexte muséal : matière première dans l'élaboration d'instruments permettant d'analyser et de cartographier le fonctionnement intellectuel d'adultes lors de leur traitement d'œuvres d'art contemporain. In C. Dufresne-Tassé \& A.M. Laraignée (Eds.), Numéro spécial sur la recherche, Volume 2 ICOM Éducation 27 (13-44). Retrieved from: https://drive.google.com/file/d/1H4RsNSMKOtiqhGSz2rf9wVBF3CRAeC4W/view

Émond, A.M. (2018). The intellectual functioning of art museums' visitors: Identifying components of a transformative aesthetic experience. In C. Pracana \& M. Wang (Eds.), Psychological applications and trends 2018 (156-160). Retrieved from: InPACT 2018_Book of Proceedings InPACT-2018_Book-Proceedings.pdf

Émond, A.M. (2019). Adult visitors' intellectual functioning exploring contemporary art: Experiences that generate self-discovery. In C. Pracana \& M. Wang (Eds.), Psychological applications and trends 2019 (101-105). Retrieved from: http://inpact-psychologyconference.org/wpcontent/uploads/2019/05/InPACT-2019_Book-Proceedings.pdf

Ericsson, K. A., \& Simon, H. A. (1993). Protocol analysis. Cambridge, MA: MIT Press. 
Gomez, J. G. (2007). What do we know about creativity? The Journal of Effective Teaching, 7(1), 31-43. Retrieved from: https://pdfs.semanticscholar.org/3ad5/30c1138e10eb674e456c3ec4ed52cb0a209c.pdf

Grimes, J.R., \& Minelli, M. (2016). La marque en tant que stratégie: les musées, les imaginaires sociaux et l'économie de l'attention. Muse, 35(1), 33-38.

Hoy, B., Wagner, L., \& Hall, E.O.C. (2007). Self-care as a health resource of elders: an integrative review of the concept. Scandinavian Journal of caring Sciences, 21(4), 456-466. Retrieved from: https://onlinelibrary.wiley.com/doi/abs/10.1111/j.1471-6712.2006.00491.x

Minissale, G. (2013). The psychology of contemporary art. New York, Cambridge University Press.

Monk, D.F. (2013). John Dewey and adult learning in museums. Adult Learning, 24(2), 63-71. Retrieved from: https://journals.sagepub.com/doi/full/10.1177/1045159513477842

Pelowski, M., \& Akiba, F. (2011). A model of art perception, evaluation and emotion in transformative aesthetic experience. New Ideas Psychology. 29, 80-97. Retrieved from: https://www.sciencedirect.com/science/article/pii/S0732118X10000413

Radford, M. (2004). Emotion and creativity. The Journal of Aesthetic Education, 38(1), 53-61. Retrieved from: https://www.jstor.org/stable/3527362?seq=1\#metadata_info_tab_contents

Riger, S., \& Lavrakas, P.J. (1981). Community ties: Patterns of attachment and social interaction in urban neighborhoods. American Journal of community Psychology, 9(1), 55-66. Retrieved from: https://onlinelibrary.wiley.com/doi/pdf/10.1007/BF00896360

Ryff, C., \& Singer, B.H. (2006). Best news yet on the six-factor model of wellbeing. Social Science Research, 35, 1103-1119. Retrieved from: doi:10.1016/j.ssresearch.2006.01.002 | Elsevier Enhanced Reader 